\title{
Aplikasi Multimedia Untuk Media Pembelajaran Menggambar Grafik Fungsi Dengan Operasi Penskalaan, Pergeseran, dan Pencerminan
}

\author{
Susana Limanto \\ Program Studi Teknik Informatika \\ Universitas Surabaya \\ susana@staff.ubaya.ac.id
}

\author{
Hendra Dinata \\ Program Studi Teknik Informatika \\ Universitas Surabaya \\ hdinata@staff.ubaya.ac.id
}

\begin{abstract}
Abstrak - Salah satu materi dari mata kuliah Matematika adalah menggambar grafik fungsi melalui operasi pergeseran, penskalaan, dan pencerminan. Materi ini disampaikan dalam waktu kurang lebih 100 menit tatap muka. Berdasarkan nilai Ujian Tengah Semester (UTS) soal menggambar grafik fungsi dari 10 kelas paralel mata kuliah Matematika semester Gasal 2016 - 2017 diketahui bahwa sekitar 79.6\% mahasiswa mendapat nilai di bawah 55 (batas nilai C). Beberapa penyebab tingginya persentase mahasiswa yang mendapat nilai di bawah $\mathrm{C}$ adalah keterbatasan waktu penyampaian materi sehingga materi disampaikan secara satu arah, yaitu dari dosen ke mahasiswa dan kebanyakan mahasiswa kurang berlatih di luar jam kuliah karena setelah berlatih tidak tahu apakah yang dikerjakannya benar atau belum. Untuk mengatasi permasalahan yang ada dikembangkan sebuah aplikasi multimedia pembelajaran yang dilengkapi dengan simulasi proses menggambar grafik fungsi melalui operasi pergeseran, penskalaan, dan pencerminan secara langkah demi langkah. Metode yang digunakan dalam penelitian terapan ini adalah prototyping yang yang terdiri dari komunikasi dengan pengguna untuk mengetahui kebutuhan pengguna, membuat prototipe, mengevaluasi prototipe berdasarkan umpan balik dari pengguna, menyempurnakan prototipe, pembuatan aplikasi, dan ujicoba aplikasi. Ujicoba aplikasi dilakukan kepada 10 orang mahasiswa peserta mata kuliah Matematika di mana materi menggambar grafik fungsi ini disampaikan dengan cara meminta para responden mencoba aplikasi secara mandiri kemudian mengisi kuisioner umpan balik. Hasil ujicoba aplikasi menunjukkan bahwa minimal $70 \%$ responden setuju bahwa aplikasi membantu untuk lebih memahami materi dan berlatih secara mandiri. Fasilitas simulasi menggambar grafik fungsi yang disajikan langkah demi langkah membantu mengkoreksi pekerjaan responden sehingga menambah kepercayaan diri responden dalam mengerjakan soal-soal selanjutnya.

Kata Kunci: Grafik Fungsi, Multimedia Pembelajaran, Pencerminan, Penskalaan, Pergeseran.
\end{abstract}

\section{PENDAHULUAN}

Fungsi adalah seperangkat aturan yang memetakan setiap anggota jika asal set (domain) untuk satu dan hanya satu anggota dari set tujuan (codomain) [1]. Grafik adalah salah satu bentuk yang menyajikan fungsi secara visual. Dan untuk menggambar grafik fungsi adalah salah satu materi yang diberikan kepada mahasiswa di Universitas Surabaya melalui mata kuliah Matematika. Pada perkuliahan itu, mahasiswa diajarkan cara menggambar grafik fungsi yang dimulai dari bentuk dasar fungsi untuk menggambar grafik fungsi dengan operasi gesekan, skala, dan refleksi.

Berdasarkan distribusi nilai Ujian Tengah Semester pada semester ganjil 2016-2017, yang dapat dilihat pada Tabel 1 berikut, menunjukkan bahwa 79,6\% mahasiswa mendapatkan nilai di bawah 55. Skor 55 adalah batas bawah untuk mendapatkan $\mathrm{C}$ di Universitas Surabaya. Ini menjelaskan bahwa banyak mahasiswa menghadapi kesulitan untuk memahami pelajaran. Wawancara dilakukan pada 3 orang dosen dan 20 mahasiswa dari kelas Matematika ini untuk menentukan penyebab rendahnya nilai ujian. Berdasarkan hasil wawancara, penyebab rendahnya skor yang didapat dari materi gambar grafik fungsi adalah waktu pengiriman bahan yang terbatas, yaitu sekitar 100 menit dan kurangnya latihan melakukan masalah di luar jam pelajaran karena setelah berlatih, mahasiswa tidak tahu apakah pekerjaan itu benar atau tidak. Keterbatasan waktu yang ada menyebabkan materi disampaikan dalam satu arah, yaitu dari dosen ke mahasiswa, mengakibatkan mahasiswa menjadi pasif dan akhirnya mahasiswa cenderung menghafal [2]. Sedangkan Matematika adalah pelajaran yang mengharuskan mahasiswa untuk secara aktif melatih untuk menguasai materi yang ada. Konsekuensinya, jika mahasiswa menemukan masalah yang berbeda dari sampel pertanyaan yang telah diberikan, mahasiswa bingung untuk menyelesaikannya.

Penelitian yang ada menunjukkan bahwa setiap mahasiswa memiliki tingkat pemahaman material yang berbeda [3]. Dan untuk meningkatkan pemahaman materi Matematika dapat dilakukan secara visual [4]. Secara khusus, dalam soal menggambar grafik fungsi, penelitian yang ada menunjukkan bahwa perangkat lunak simulasi dapat diadopsi untuk memahami pelajaran itu $[4,5,6,7,8]$. 
Bahkan aplikasi itu sendiri dapat digunakan untuk meningkatkan kualitas pembelajaran di kelas [9].

Tabel 1. Distribusi Nilai UTS Soal Menggambar Grafik Fungsi

\begin{tabular}{lrr}
\hline \multicolumn{1}{c}{ Range Nilai } & $\begin{array}{c}\text { Jumlah } \\
\text { Mahasiswa }\end{array}$ & $\begin{array}{c}\text { \% Jumlah } \\
\text { Mahasiswa }\end{array}$ \\
\hline Nilai ujian $\geq 81$ & 34 & 9 \\
$73 \leq$ nilai ujian $<81$ & 3 & 0,8 \\
$66 \leq$ nilai ujian $<73$ & 1 & 0,3 \\
$60 \leq$ nilai ujian $<66$ & 39 & 10,3 \\
$55 \leq$ nilai ujian $<60$ & 0 & 0 \\
$40 \leq$ nilai ujian $<55$ & 17 & 4,5 \\
nilai ujian $<40$ & 285 & 75,1 \\
\hline Total & 379 & 100 \\
\hline
\end{tabular}

Untuk itu pada penelitian yang dilakukan, dikembangkan sebuah perangkat lunak multimedia untuk mensimulasikan proses menggambar grafik fungsi linier, fungsi kuadrat, logaritma, dan akar. Perangkat lunak simulasi ini diharapkan dapat membantu mahasiswa untuk berlatih secara mandiri di luar kelas karena dilengkapi dengan penjelasan langkah demi langkah penggambaran grafik fungsi. Alat bantu pembelajaran tersebut harus dapat saling berinteraksi dengan penggunanya, karena proses interaksi ini juga merupakan komponen yang sangat penting di dalam proses pembelajaran [3].

\section{TINJAUAN PUSTAKA}

Beberapa penelitian untuk meningkatkan pemahaman siswa tentang fungsi grafik telah dilakukan. Salah satunya adalah penelitian yang dilakukan untuk meningkatkan pemahaman siswa SMA konsep grafik fungsi trigonometri melalui penemuan dipandu dengan bantuan perangkat lunak Autograph [6]. Siswa yang menjadi objek dalam penelitian adalah siswa yang sudah memiliki kemampuan menjalankan perangkat lunak Autograph. Hasil penelitian menunjukkan bahwa pendekatan penemuan terbimbing Autograph Software meningkatkan pemahaman siswa tentang konsep grafik fungsi trigonometri.

Penelitian lain yang telah dilakukan adalah mendeskripsikan penalaran siswa dalam menggambar grafik fungsi melalui pengembangan perangkat lunak simulasi grafis fungsi linear dan fungsi kuadrat [5]. Representasi grafik fungsi linear dan fungsi kuadrat dilakukan dengan mengambil beberapa titik. Poin yang diambil untuk menggambar fungsi linear adalah $x=1,2,3,4,5$ dan poin yang diambil untuk menggambar fungsi kuadrat adalah $x=$ $4,-2,0,2,4$. Mengambil poin yang pasti, terkadang bisa membuat visualisasi bentuk grafis menjadi tidak jelas. Hasil penelitian yang dilakukan menunjukkan bahwa sebagian besar peserta didik pada materi menggambar grafik fungsi kuadrat memiliki kompetensi yang sangat rendah [7]. Hal ini disebabkan kurangnya keterlibatan siswa dalam menemukan konsep Matematika dan tidak memanfaatkan media dalam proses pembelajaran. Metode pembelajaran penemuan koperatif digunakan untuk mengatasi masalah yang ada dan dibantu oleh perangkat lunak GeoGebra. Hasil penelitian menunjukkan bahwa penggunaan perangkat lunak dapat meningkatkan kemampuan siswa dalam mengenali karakteristik grafik fungsi kuadrat dan menggambar grafik.

Setiap siswa memiliki tingkat pemahaman (gaya kognitif) pada materi grafik fungsional yang berbeda [3] Penelitian dilakukan untuk mengetahui tingkat pemahaman siswa yang memiliki gaya Independen Field (IF) dalam menggambar grafik fungsi. Gaya kognitif IF adalah gaya seseorang yang tidak mudah dipengaruhi oleh lingkungan. Hasil penelitian ini menunjukkan bahwa siswa dengan gaya kognitif IF mampu menggambarkan grafik fungsi sesuai dengan langkah-langkah yang telah ditentukan.

Pelajaran trigonometri adalah kelompok materi yang paling sulit dalam Matematika [8]. Hal ini dapat dilihat dari jumlah siswa yang tidak suka dan mendapat skor rendah pada materi ini dibandingkan dengan materi lain dalam Matematika. Salah satu faktor utama yang menyebabkan hal ini adalah kurangnya inovasi guru dalam menyampaikan materi trigonometri. Untuk itu, Tamurih mengembangkan alternatif untuk pengajaran trigonometri menggunakan grafik sinus dan kosinus. Hasilnya menunjukkan bahwa metode ini membantu siswa untuk memahami pelajaran trigonometri dan membantu guru untuk menjadi kreatif secara visual.

\section{METODOLOGI PENELITIAN}

Penelitian ini dilakukan dengan menggunakan metode prototipe karena merupakan pendekatan terbaik untuk mengembangkan aplikasi multimedia [10]. Rancangan cara kerja penelitian yang dilakukan secara garis besar dapat dilihat pada Gambar 1. Tahap pertama dari metode ini adalah pengumpulan data melalui komunikasi langsung dengan pengguna. Wawancara dilakukan dengan 3 orang dosen dan 20 mahasiswa yang mengambil kuliah Matematika. Data yang dikumpulkan digunakan untuk menyusun aplikasi yang perlu dibangun. Berdasarkan kebutuhan yang berhasil diringkas, maka dibangunlah prototipe. Ini dilakukan untuk mengurangi kesalahpahaman dengan pengguna. Prototipe ini berisi desain awal aplikasi yang akan dikembangkan, yang berisi desain antarmuka pengguna aplikasi. Prototipe ini kemudian dikomunikasikan dengan pengguna untuk mendapatkan umpan balik. Umpan balik diperoleh, digunakan untuk menyempurnakan prototipe yang ada. Ini dilakukan berulang kali hingga pengguna setuju dengan prototipe yang terbentuk. Setelah prototipe disetujui oleh pengguna, maka aplikasi dibuat. Aplikasi ini dikembangkan dengan Microsoft Visual Studio C\#. Aplikasi yang selesai dikembangkan diuji dengan metode pengujian black box untuk memastikan bahwa semua fitur yang disediakan berjalan dengan benar sebelum aplikasi diuji kepada pengguna. Aplikasi yang diuji oleh sepuluh pengguna dalam hal ini adalah mahasiswa peserta mata kuliah Matematika pada semester ganjil 2017-2018. Pemilihan responden dilakukan dengan simple random sampling. Pengujian 
dilakukan dengan memberi kesempatan kepada mahasiswa terpilih untuk mencoba aplikasi secara mandiri dan kemudian diminta memberikan umpan balik dalam bentuk kuisioner.

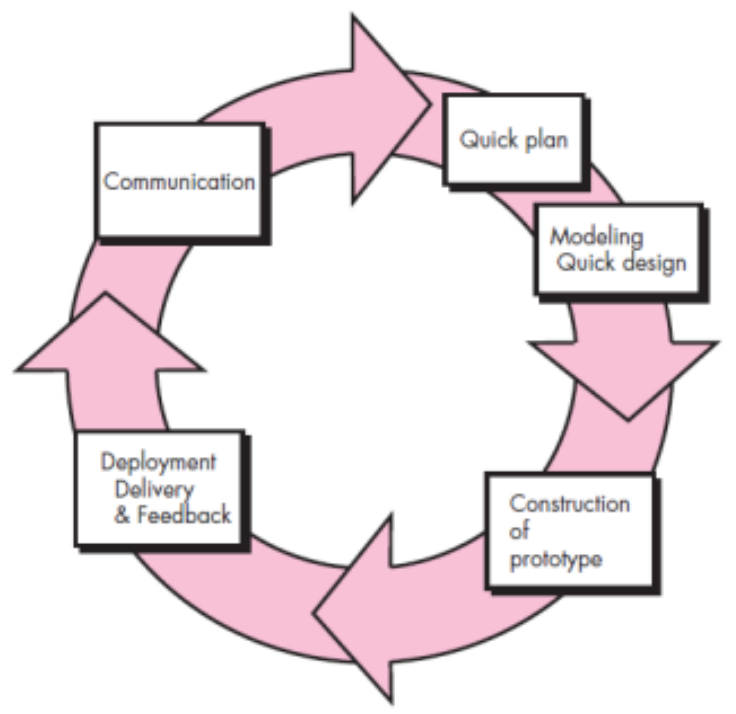

Gambar 1. Metode Prototipe

\section{HASIL DAN PEMBAHASAN}

Agar aplikasi multimedia yang dibangun dapat menjadi alat dalam proses belajar mengajar, maka aplikasi ini dirancang sedemikian rupa sehingga dapat mendukung proses interaksi di dalamnya, yang merupakan komponen yang sangat penting $[11,12]$. Aplikasi dapat dirancang dengan menyoroti keuntungan dari aplikasi berbasis multimedia yaitu dengan menambahkan gambar, suara, teks, video atau animasi di setiap bagian aplikasi [13]. Ini dilakukan karena pengguna sistem pembelajaran sebenarnya juga membutuhkan sistem yang juga dilengkapi dengan animasi untuk membantu memberikan gambaran tentang bagaimana hal-hal bekerja selain hanya teks dan gambar [14].

Aplikasi pembelajaran multimedia ini dibangun sebagai aplikasi multimedia berbasis desktop menggunakan C\# .Net sebagai bahasa pemrogramannya. Ini dibuat untuk didistribusikan kembali ke mahasiswa dan dapat digunakan kembali di rumah bahkan jika koneksi internet tidak tersedia. Aplikasi ini dapat dibangun menggunakan Microsoft Visual Studio .NET sebagai pembuatnya tanpa menggunakan komponen pihak ketiga, baik untuk mengeluarkan suara, menggambar grafik dan memainkan animasi dalam proses menggambar grafik. Sedangkan untuk animasi pada proses menggambar grafik, dapat memanfaatkan objek Timer. Fungsi Graphic.DrawLine() dapat digunakan untuk menghasilkan grafik fungsi. Namun, fungsi ini dapat menghasilkan garis lurus saja dan bukan garis lengkung. Untuk menghasilkan efek garis lengkung, perlu untuk menentukan titik-titik di sepanjang garis lengkung. Kumpulan titik-titik dihasilkan oleh aplikasi sesuai dengan persamaan fungsi dengan memasukkan nilai $x$ yang mewakili titik koordinat pada media gambar PictureBox. Seperti dapat dilihat pada Gambar 2, titik 0 dan titik 2 pada sumbu-x adalah $x_{0}$ dan $x_{\mathrm{n}}$. Kemudian, antara $x_{0}$ dan $x_{\mathrm{n}}$ ditentukan sejumlah titik baru, yaitu $x_{1}, x_{2}, x_{3}$, hingga $x_{\mathrm{n}}$. Iterasi dilakukan mulai dari $x_{0}$ hingga $x_{\mathrm{n}}$ untuk menghasilkan pasangan titik koordinat $\left(x_{\mathrm{i}}, y_{\mathrm{i}}\right)$ dengan menghitung nilai $y_{\mathrm{i}}$ sesuai dengan persamaan fungsi. Setelah mendapatkan sepasang titik koordinat $\left(x_{\mathrm{i}}, y_{\mathrm{i}}\right)$, maka iterasi lain dapat dimulai dari $\mathrm{i}=0$ hingga $\mathrm{i}<\mathrm{n}$ untuk menghasilkan garis yang ditarik dari titik $\left(x_{\mathrm{i}}, y_{\mathrm{i}}\right)$ ke titik $\left(x_{\mathrm{i}}+1, y_{\mathrm{i}}+1\right)$. Semakin dekat antara titik $x_{\mathrm{i}}$ ke titik $x_{\mathrm{i}}+1$, semakin baik gambar garis yang dihasilkan menyerupai lengkungan.

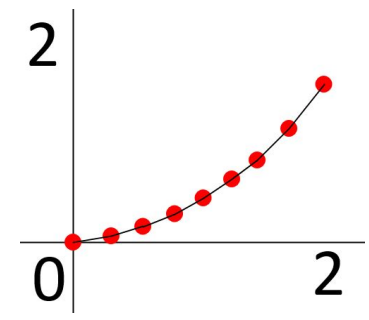

Gambar 2. Gambar Grafik Fungsi yang Dihasilkan Dari Sekumpulan Garis Lurus

Aplikasi yang dikembangkan ini terdiri dari empat menu utama. Menu-menu tersebut adalah "Materi", menu "Contoh Soal", menu "Latihan", dan menu "Test".

Menu "Materi" berisi definisi dan penjelasan konsep fungsi, operasi shift, skala, dan refleksi yang disajikan dalam bentuk teks, gambar, audio, dan penggambaran grafis animasi. Seperti dapat dilihat pada Gambar 3, pengguna dapat membaca isi penjelasan di kolom sebelah kiri, dan di sebelah kanan diberikan animasi untuk mengilustrasikan isi penjelasan yang ada di kolom kiri. Sebagai aplikasi multimedia, suara atas isi penjelasan di kolom kiri juga dimainkan secara bersamaan. Sebagai bagian dari proses interaksi, pengguna dapat menekan tombol "Sebelumnya" atau "Selanjutnya" untuk menampilkan penjelasan berikutnya karena beberapa penjelasan tidak ditampilkan dalam satu bingkai secara bersamaan tetapi dibagi menjadi beberapa bingkai.

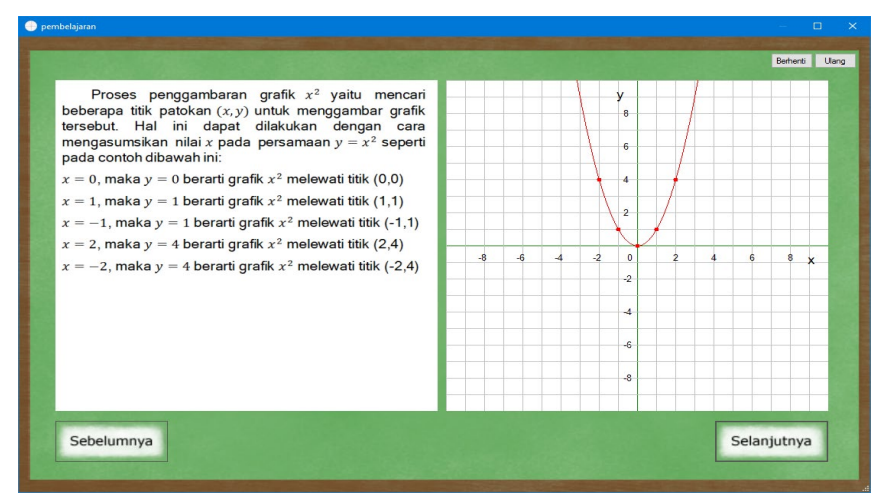

Gambar 3. Halaman Materi yang Berisikan Penjelasan Tentang Fungsi 
Di menu "Contoh Soal", pengguna dapat melihat contoh pertanyaan yang dibuat secara acak oleh aplikasi. Di kolom sebelah kiri, pengguna dapat melihat contoh gambar grafik dari persamaan fungsi yang diberikan, bersama dengan penjelasan langkah demi langkah tentang cara menghasilkan gambar. Tidak seperti menu "Contoh Masalah", pada menu "Latihan", pengguna memilih untuk berlatih menggambar grafik pada persamaan fungsi dasar. Ada empat bentuk dasar fungsi. Setelah memilih salah satu dari mereka, pengguna diminta untuk mengisi nilai koefisien. Contoh:

a. Pada fungsi dasar $\mathrm{f}(x)=x^{2}$, maka koefisien yang dapat diisikan oleh pengguna yaitu a, b, c, d sehingga akan membentuk persamaan $\mathrm{f}(x)=\mathrm{a}(\mathrm{b} x+\mathrm{c})^{2}+\mathrm{d}$

b. Pada fungsi dasar $\mathrm{f}(x)=x$, maka koefisien yang dapat diisikan oleh pengguna yaitu a, b, c, d sehingga akan membentuk persamaan $\mathrm{f}(x)=\mathrm{a}(\mathrm{b} x+\mathrm{c})+\mathrm{d}$

c. Pada fungsi dasar $\mathrm{f}(x)=\mathrm{a}^{x}$, maka koefisien yang dapat diisikan oleh pengguna yaitu $\mathrm{a}, \mathrm{b}, \mathrm{c}, \mathrm{d}$ dan e sehingga akan membentuk persamaan $\mathrm{f}(x)=\mathrm{a} \cdot \mathrm{b}^{\mathrm{c} x+\mathrm{d}}+\mathrm{e}$

d. Pada fungsi dasar $\mathrm{f}(x)=\log x$, maka koefisien yang dapat diisikan oleh pengguna yaitu a, b, c, d sehingga akan membentuk persamaan $\mathrm{f}(x)=\mathrm{a} \log (\mathrm{b} x+\mathrm{c})+\mathrm{d}$

Gambar 4 adalah contoh halaman "Latihan" dengan fungsi kuadrat $y=x^{2}$. Pengguna memasukkan nilai koefisien, misalnya $\mathrm{a}=4, \mathrm{~b}=2, \mathrm{c}=6$, dan $\mathrm{d}=8$. Nilai-nilai koefisien ini untuk memenuhi rumus dasar dari fungsi kuadrat, yaitu: $\mathrm{y}=\mathrm{a}(\mathrm{b} x+\mathrm{c})^{2}+\mathrm{d}$. Aplikasi akan mulai memproses dengan menampilkan grafik animasi dari fungsi ini. Untuk mendukung proses pembelajaran, gambar grafik yang dihasilkan tidak langsung menyajikan gambar grafik akhir. Namun, aplikasi akan menyajikan langkah demi langkah sehingga pengguna juga dapat memahami apa arti dari setiap koefisien a, b, c, dan d. Aplikasi akan menyajikan proses penggambaran grafik yang dibagi menjadi lima langkah.

- Langkah 1: Aplikasi menggambarkan grafik sesuai fungsi dasar $y_{1}=x^{2}$

- Langkah 2: $y_{1}$ berkembang menjadi $y_{2}=(2 x)^{2}$. Karena nilai koefisien $\mathrm{b}=2$ maka skala horizontal dikompresi ke arah sumbu $x$ dengan faktor skala $1 / 2$ unit. Skala horizontal dikompresi ke arah sumbu $x$ sebagai nilai $x$ berubah menjadi $(2 x)$

- Langkah 3: $y_{2}$ berkembang menjadi $y_{3}=(2 x+6)^{2}$. Pengguna memberikan nilai koefisien $\mathrm{c}=6$ maka $\mathrm{y} 3$ dapat diubah menjadi $y_{3}=2(x+3)^{2}$ dari bentuk asli $y_{3}=$ $(2 x+6)^{2}$ sehingga terjadi pergeseran horizontal ke kiri 3 unit. Pergeseran horizontal ke kiri karena nilai $x$ berubah menjadi $(x+3)$.

- Langkah 4: $y_{3}$ berkembang menjadi $y_{4}=4(2 x+6)^{2}$. Pengguna memasukkan nilai koefisien $a=4$ kemudian skala vertikal ditarik dalam arah sumbu y oleh 4 . Skala vertikal ditarik ke arah sumbu y karena nilai $y$ berubah menjadi 4 kali nilai $y$ asli $\left(y_{4}=4 y_{3}\right)$.

- Langkah 5: $y_{4}$ dikembangkan menjadi $y_{5}=4(2 x+6)^{2}+$ 8. Nilai koefisien $\mathrm{d}=8$, maka ada pergeseran vertikal ke atas 8 unit. Pergeseran vertikal ke atas karena nilai $y$ meningkat sebanyak 4 unit dari nilai $y$ asli $\left(y_{5}=y_{4}+8\right)$.

Aplikasi ini juga diujicobakan kepada sepuluh mahasiswa yang mengikuti kuliah Matematika, yaitu mata kuliah di mana materi menggambar grafik fungsi ini disampaikan. Pemilihan kesepuluh responden dilakukan secara simple random sampling dan didapati bawah kesepuluh responden adalah mahasiswa yang memang baru pertama kali

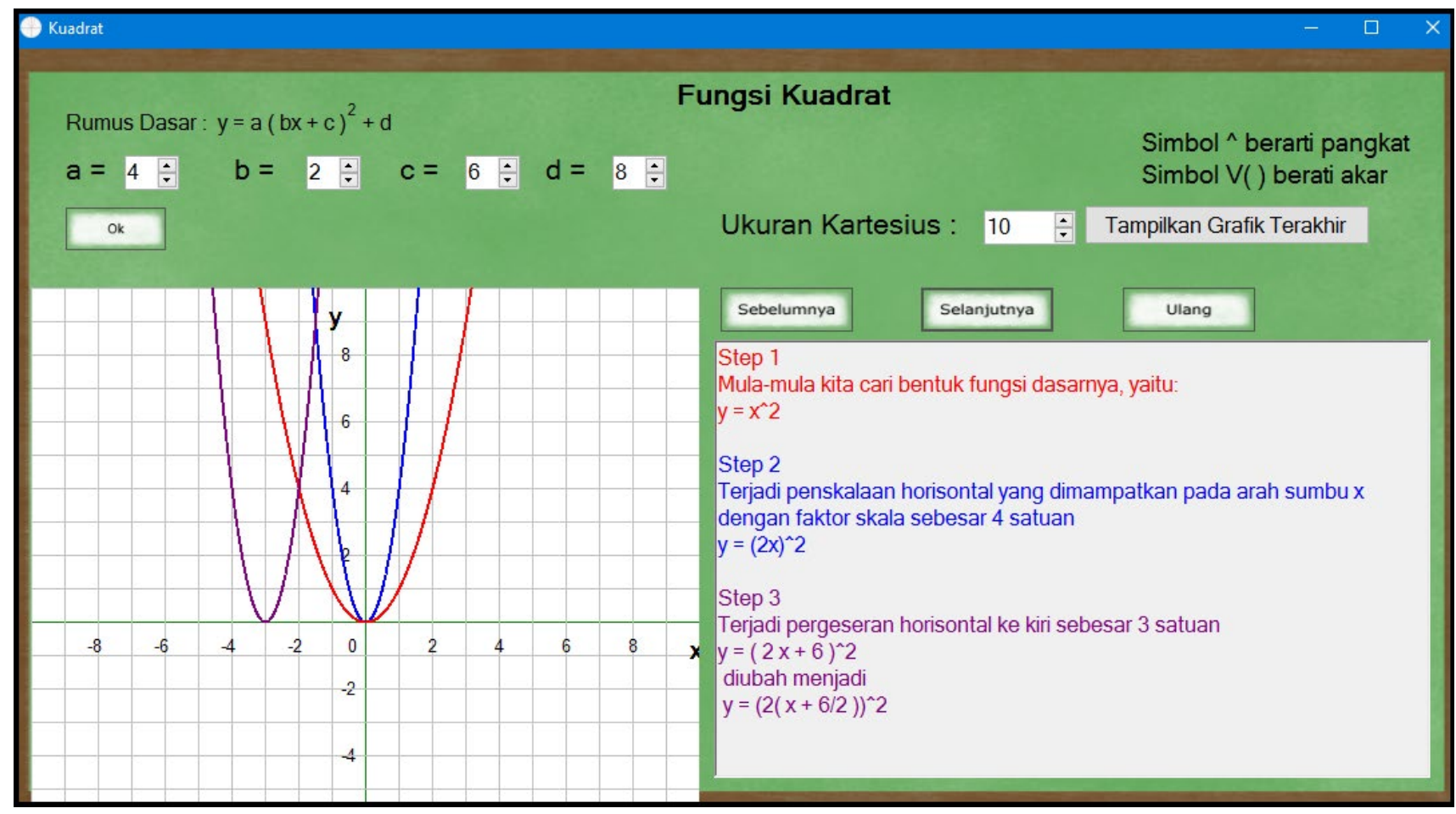

Gambar 4. Halaman Latihan Pada Fungsi Dasar $x^{2}$ 
mengikuti mata kuliah Matematika ini dan bukan mahasiswa yang sedang mengulang mata kuliah Matematika dengan enam di antaranya memiliki IPK di atas 3.0 dan empat sisanya memiliki IPK di bawah 3.0. Mahasiswa diberikan kesempatan pertama untuk mencoba dan memahami cara menggunakan aplikasi terlebih dulu lalu kemudian melakukannya secara mandiri untuk mencoba latihan soal tentang fungsi grafik yang ada di dalamnya termasuk menu "Test". Menu "Test" berisi sejumlah pertanyaan pilihan ganda yang dihasilkan secara acak oleh sistem dan pengguna akan memilih satu jawaban yang menurutnya jawaban yang paling sesuai. Setelah itu, mahasiswa diminta untuk mengisikan kuisioner untuk melihat umpan balik dari pengguna apakah aplikasi pembelajaran menggambar grafik fungsi ini telah mampu menjawab permasalahan yang ada dan telah sesuai dengan kebutuhan mereka. Tabel 2 berikut di bawah ini adalah hasil kuisioner yang didapatkan.

Tabel 2. Hasil Kuisioner

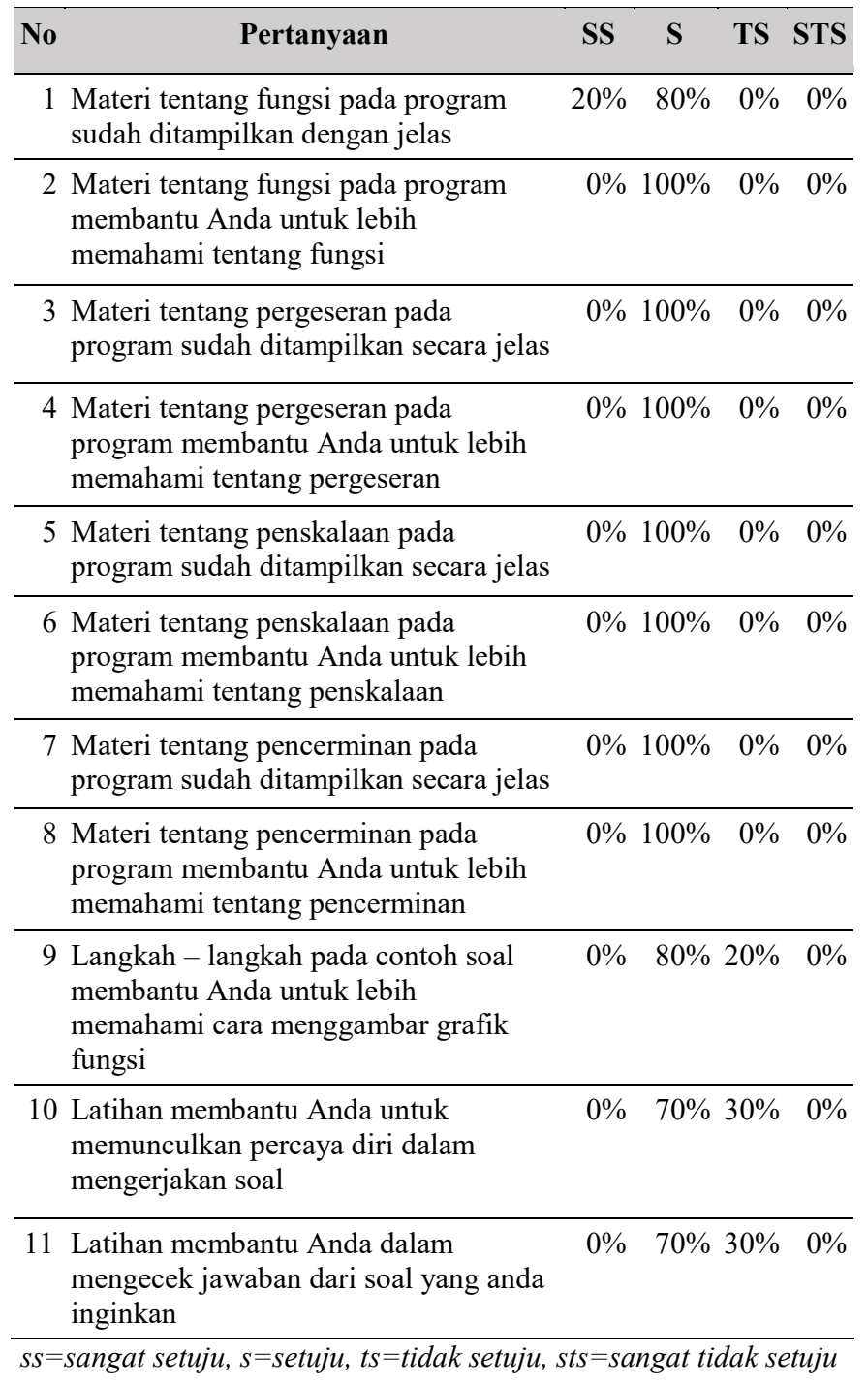

Dari hasil kuisioner yang didapat ini lebih dari tujuh puluh persen mahasiswa setuju bahwa program telah menampilkan materi dengan jelas. Materi yang disajikan pada aplikasi membantu pengguna untuk lebih memahami materi menggambar grafik fungsi. Langkah-langkah pada contoh soal membantu lebih memahami cara menggambar grafik fungsi serta latihan membantu dalam memeriksa jawaban dari soal yang diinginkan dan hal ini dapat membantu mahasiswa memunculkan kepercayaan diri mereka dalam mengerjakan soal-soal. Beberapa mahasiswa memilih tidak setuju dikarenakan ketika mencoba latihan pada program rasa percaya diri yang mereka miliki tidak berubah dan saat mengerjakan test tidak bisa membuka menu latihan di saat yang bersamaan.

\section{KESIMPULAN}

Proses pembelajaran menggambar grafik fungsi linier, kuadrat, logaritma dan akan dengan operasi penskalaan, pergeseran dan pencerminan dapat dilakukan dengan bantuan sebuah aplikasi multimedia pembelajaran. Aplikasi ini dapat digunakan dan materi di dalamnya dapat dipelajari secara mandiri oleh mahasiswa. Soal-soal latihan yang ada di dalam aplikasi ini telah dapat membantu mahasiswa dalam berlatih dan memahami materi menggambar grafik fungsi.

\section{REFERENSI}

[1] Liu, C.L.D. (1995). Dasar-Dasar Matematika Diskret. Edisi 2. Jakarta: Gramedia Pustaka Utama.

[2] Darmadi. (2017). Identifikasi Kesalahan Berpikir Visual Mahasiswa dalam Menggambar Grafik Fungsi Real. Math Didactic: Jurnal Pendidikan Matematika, Vol. 3 No. 2, Mei - Agustus 2017, Hal. 140-144.

[3] Mulyono. (2010). Konstruksi Pemahaman Konsep Grafik Fungsi Mahasiswa Bergaya Kognitif Field Independent. Jurnal Pendidikan Matematika dan Sains, Edisi 2 Tahun XV 2010, Hal. 57 - 63.

[4] Darmadi. (2012). Membangun Pembelajaran Matematika yang Menyenangkan dengan Visualisasi. Seminar Nasional UNY, Yogjakarta, 24 Maret 2012.

[5] Chandra, T. (2017). Perancangan Perangkat Lunak Penggambaran Grafik berserta Penyelesaian Fungsi Persamaan Linear dan Kuadrat. Jurnal Times (Technology Informatics and Computer System), Vol. 6 No. 1, Juni 2017, Hal 26-30.

[6] Saragih, S. dan Afriati, V. (2012). Peningkatan Pemahaman Konsep Grafik Fungsi Trigonometri Siswa SMK melalui Penemuan Terbimbing Berbantuan Software Autograph. Jurnal Pendidikan dan Kebudayaan, Vol. 18, No. 4 , Hal. 368-381.

[7] Siregar, S. (2017). Efektivitas Penggunaan Simulasi Geogebra Pada Pembelajaran Grafik Fungsi Kuadrat. Edumatica: Jurnal Pendidikan Matematika, Vol. 7, No. 01, Hal. 11-20.

[8] Tamurih. (2016). Sudut-Sudut Berelasi Dengan Grafik Fungsi Sinus dan Cosinus. MATHLINE, Jurnal Matematika dan Pendidikan Matematika, Vol. 1, No. 1, Feb 2016, Hal. 53-62. 
[9] Guan, N., Song, J. dan Li, D. (2018). On The Advantages of Computer Multimedia-aided English Teaching. Procedia Computer Science, Vol. 131, Hal. 727-732

[10] Pressman, R.S. dan Maxim, B.R. (2015) Software Engineering: A Practitioner's Approach, Edisi 8, United States of America: McGraw-Hill Education.

[11] Wibawanto, W. (2017). Desain dan Pemrograman Multimedia Pembelajaran Interaktif. Jember: Penerbit Cerdas Ulet Kreatif.
[12] Susilana, R. dan Riyana, C. (2009). Media Pembelajaran. Hakikat, Pengembangan, Pemanfaatan, dan Penilaian. Bandung: CV Wacana Prima.

[13] Oka, G.P.A. (2017). Media dan Multimedia Pembelajaran. Yogyakarta: CV Budi Utama.

[14] Adelia, T. dan Limanto, S. (2017). Pemanfaatan Multimedia Sebagai Media Pembelajaran Untuk Meningkatkan Pemahaman Siswa Terhadap Materi Fisika Elektromagetik. Teknika, Vol. 6, No. 1, Hal. 3542, ISSN 2549-8037, EISSN 2549-8045. 